\title{
Devising an Effective Management Strategy against Brinjal Shoot and Fruit Borer [Leucinodes orbonalis (Guenee)] under Hill Agriculture in Uttarakhand, Himalayas
}

\author{
Jaiprakash Gupta ${ }^{1}$, ARNS. Subbanna ${ }^{1}$, Johnson Stanley ${ }^{2}$, \\ Amit Umesh Paschapur ${ }^{1 *}$ and Krishna Kant Mishra ${ }^{1}$ \\ ${ }^{1}$ ICAR-Vivekananda Parvatiya Krishi Anusadhana Sansthan, Almora, \\ Uttarakhand-263601, India \\ ${ }^{2}$ ICAR-Indian Institute of Millet Research, Hyderabad, Telangana- 500030, India \\ *Corresponding author
}

\section{Keywords}

Brinjal shoot and fruit borer,

Insecticides,

Botanical, Per cent yield increase, Per cent pest reduction

Article Info

Accepted:

04 October 2020

Available Online:

10 November 2020

\begin{abstract}
A B S T R A C T
Brinjal shoot and fruit borer (BSFB) (Leucinodes arbonalis Guenee) is an obnoxious pest causing severe yield loss to an extent of $70-92 \%$ and rendering the fruits unmarketable and unfit for consumption. Although a number of insecticides can effectively manage the pest, unethical and injudicious spray of insecticides causes pest resurgence, health hazards and pesticide residues in edible fruits. The present study focused on ETL based application of 3 insecticides imidacloprid 17.8 SL, spinosad 45 SC and carbofuran 3G, one botanical, Nimbicidine @ $0.03 \%$ EC and mechanical method of clipping infected shoots and fruits after every 10 days interval during Kharif 2017 and 2018. The treatment with Imidacloprid 17.8 SL proved to be the best with per cent pest reduction of as high as $75 \%$ and highest per cent yield increase of $77.81 \%$. Moreover, spinosad 45 SC yielded $65.70 \%$ more yield than control in the second year, followed by Carbofuron 3G $(56.84 \%)$, Nimbicidine @ $0.03 \%$ EC (54.75\%) and manual clipping (25.84\%). While, in the first year too, the similar trend of per cent yield increase and per cent pest reduction was recorded. Finally it was concluded that Imidocloprid 17.8 SL was the most efficient insecticide against BFSB and was recommended to be used in rotation with spinosad $45 \mathrm{SC}$, carbofuran $3 \mathrm{G}$ and Nimbicidine @ $0.03 \%$ EC to avoid resistance development and in integration with regular clipping of infected shoots and fruits to achieve successful pest management.
\end{abstract}

\section{Introduction}

Brinjal (Solanum melongena $\mathrm{L}$ ) is one of the widely cultivated and consumed vegetable in many countries including India, China, South East Asia, South East Europe and several American and African countries (Lovelock 1972; Harish et al., 2011). Brinjal or Egg plant or aubergine is native to India and grown in all three seasons in the country. It is widely accepted and valued for its high nutritive value like, rich in iron, phosphorous, calcium and vitamins A, B and C. India is the second largest producer of Brinjal after Bangladesh, with an area of 733.16 thousand hectares under cultivation and production of 
12510.48 thousand MT which accounts for $24.5 \%$ share of world production (indiastat.com). Uttrakhand state is well known for the production of off season vegetables and brinjal is one among them with productivity of $12.20 \mathrm{MT} / \mathrm{Ha}$, cultivated area of 2.57 thousand hectares and production of 31.34 thousand MT (Welfare 2019).

Brinjal is attacked by plethora of insect and mite pests starting from seedling to senescence stage (Reghupathy et al., 1997). A survey carried out by the Asian Vegetable Research and Development Center (AVRDC 1995) indicated that the shoot and fruit borer (Leucinodes arbonalis Guenee), cotton leaf hopper, (Amrasca bigutulla bigutulla Ishida) and epilachna beetle, (Henosepilachna vigintictopnuctata Fabricius) are the destructive pests on brinjal in Asia. Independently, shoot and fruit borer was identified as the primary limiting factor in brinjal cultivation in the entire South Asian region (FAO, 2007; Rahman, 2006; Taylo et al., 2016). The pest can damage the crop throughout the year and reported from all brinjal growing areas of the world including Germany, Burma, USA, Srilanka and India (Dhankar, 1988; Islam and Karim, 1991; Rahman 1997; Alam et al., 2003; Taylo et al., 2016). Both the early and late instar larvae of BSFB cause severe damage to fruits and shoots of the crop. The larvae tunnel into Petioles, midribs of large leaves, young tender shoots and ripening fruits. Due to larval activity, translocation of nutrients towards shoots is affected further leading to withering and drooping of shoots (Atwal and Dhaliwal 2007). The pest is known to infect brinjal plants in all stages of its growth and yield loss to an extent of 70-92 percent is reported in severe cases of infestation (Eshwara Reddy and Srinivasa 2004; Jagginavar et al., 2009; Chakraborti and Sarkar 2011). Moreover, the infested fruits become unfit for consumption due to loss of quality and become unmarketable, causing huge economic loss to the farmer.

Keeping the above back drops in mind and considering the severe infestation of $L$. arbonalis in Brinjal cultivated areas of Uttarakhand, India. An investigation was planned to evaluate the best management strategy against Brinjal shoot and fruit borer. The well known farmers practice of clipping and destruction of infested plant parts at regular intervals, soil application of carbofuron $3 \mathrm{G}$ a broad spectrum insecticide and foliar spray of Imidacloprid for management of sucking pests in brinjal were selected as three treatments. While, a novel insecticide Spinosad 45 SC widely recommended for management of $L$. arbonalis and Nimbicidine $0.03 \%$ EC used in organic pest management programmes were chosen as other two treatments. The per cent pest reduction and yield advantages were calculated for each treatment and the best management strategy was recommended to the farmers for effective pest management.

\section{Materials and Methods}

The present investigation was carried out at Krishi Vigyan Kendra, Chinyalisaur $\left(30.584^{0} \mathrm{~N}, \quad 78.315^{\circ} \mathrm{E}\right), \quad$ Uttarkashi, Uttarakhand (India) under rain fed condition at 755 AMSL. The two trials were conducted during kharif 2017 and kharif 2018 in randomized black design (RBD) with a plot size of $6 \times 3 \mathrm{~m}$. The seedlings were transplanted on $22^{\text {nd }}$ June 2017 and $23^{\text {rd }}$ May 2018. Brinjal variety BE 706 (F1 hybrid) was raised with proper fertilization as per recommended package of practices of ICARVPKAS, Almora. Six treatments were selected that comprised of one botanical (Nimbicidine @ $0.03 \%$ EC azadirachtin; Stanes), three insecticides viz., imidacloprid 17.8 SL (Sacdor @ 17.8\% SL; Shivalik crop sciences), spinosad 45 SC (Conserve@45 
SC; Nagarjun Agrichem Ltd.) and carbofuran 3G (Furadan 3G; FMC) and a mechanical strategy of clipping and destruction of infested plant parts (both infected shoots and fruits). The treatments were imposed for two consecutive years after considering the Economic Threshold Level (ETL) of 5\% shoot damage and $10 \%$ fruit damage at vegetative and reproductive stage respectively. While, each treatment was replicated four times. In each season, all the treatments were imposed two times except for the clipping of infested plant parts which was done regularly at 10 days interval throughout the crop season. The insecticides were applied with the help of a knapsack sprayer up to the point of runoff with spraying capacity $1600 \mathrm{cc}$ min-1 and working pressure $4.5 \mathrm{~kg} \mathrm{~cm}-2$. Carbofuran 3G was applied as soil treatment near the root zone at the rate of 4-5 gram per plant. The details and rate of application of different treatments are furnished in table 1.

\section{Data collection}

A total of five plants were randomly tagged in each plot to record number of damaged shoots/fruits per plot, 7 and 14 days after treatment and the data was expressed as percent shoot and fruit infestation per plot. The final data on the yield of each plot was calculated to estimate the yield advantage over control.

\section{Data analysis}

The pre-treatment count (PTC) was recorded in both vegetative and reproductive stage and the values were converted into percentage. The data on per cent pest reduction and per cent yield increased were calculated by the following formula (Formula 1 and 2) and all the values were arcsine transformed before analysis. The statistical software package WASP 2.0 (Web Based Agricultural Statistics Software Package) developed by ICAR-
Central Coastal Agricultural Research institute (CCARI) - Goa, India was used for data analysis.

Per cent pest reduction= $($ PTC $-\%$ damage after treatment $)$
................Formula 1. PTC

Per cent yield increase $=\underline{(\text { Yield obtained in treated plot }- \text { Yield in control }) X}$ 100 .......Formula 2 .

Yield in control

\section{Results and Discussion}

The present investigation estimated the damage caused by brinjal shoot and fruit borer in both vegetative and fruiting stages under Indian Himalayan conditions and its possible control strategies (Data presented in table 2 and 3). In the first year (Kharif-2017), the PTC data showed that, the variation in pest infestation in different plots was nonsignificant, indicating the even distribution of the pest throughout the field. While, the per cent pest infestation drastically reduced after the first spray and significant reduction in pest damage with respect to control was observed both 7 and 14 days after treatment. A maximum of $59.1 \%$ pest reduction was recorded in plants treated with Imidacloprid 17.8 SL, followed by $54.5 \%$ with Spinosad 45 SC, $49.7 \%$ and $45.3 \%$ with carbofuron $3 \mathrm{G}$ and Nimbicidine $0.03 \%$ EC respectively after 7 days of treatment. However, manual clipping of the infected plant parts could only partially reduce the infestation, but per cent pest reduction was significantly superior over control. The second PTC recorded before reproductive stage showed the significant variation in pest population and per cent infestation among the treatments. Moreover, the per cent pest reduction after second treatment was highly significant with respect to control. Wherein, a highest of $75 \%$ pest reduction was observed in Imidacloprid 17.8 SL treated plants, followed by manual clipping, Spinosad 45 SC, carbofuron $3 \mathrm{G}$ and 
Nimbicidine $0.03 \%$ EC that recorded per cent pest reduction of $69.1 \%, 67.8 \%, 66.2 \%$ and $59.5 \%$ respectively. The results on the per cent yield increase after different treatments showed that Imidacloprid 17.8 SL was highly effective insecticide with maximum per cent yield increase of $44.37 \%$, which was followed by Spinosad 45SC (38.24\%), carbofuron 3G (36.01\%), nimbicidine $0.03 \%$ EC and manual clipping $(28.21 \%)$.

In the second year (Kharif-2018), due to early transplanting of the brinjal seedlings $\left(23^{\text {rd }}\right.$ May 2018) the PTC readings before first treatment were varying significantly, indicating the uneven distribution of the pest population in the field. The per cent pest reduction 7 days after first treatment also showed that the plots treated with Imidacloprid $17.8 \mathrm{SL}$ recorded $60.16 \%$ pest reduction, followed by Spinosad $45 \mathrm{SC}$, carbofuron $3 \mathrm{G}$ and Nimbicidine $0.03 \% \mathrm{EC}$ that recorded $52.94 \%, 48.59 \%$ and $46.75 \%$ respectively. However, the per cent reduction in pest population by manual clipping was significantly superior over the control. In the second spray during reproductive stage, the PTC results were significantly varying between the plots and the insecticide treatments drastically reduced the pest population after 7 and 14 days of spray. The lowest per cent pest reduction was recorded in nimbicidine $0.03 \%$ EC (43.21\%) treated plots, while the highest per cent pest reduction was recorded in Imidacloprid 17.8 SL (66.90\%) treated plots. While, Spinosad $45 \mathrm{SC}$, carbofuron $3 \mathrm{G}$ and manual clipping recorded $56.61 \%, 44.27 \%$ and $51.97 \%$ pest reduction respectively. It was interesting to note here that, the treatment of manual clipping of infested plant parts was superior over carbofuron $3 \mathrm{G}$ and nimbicidine $0.03 \% \mathrm{EC}$. The results regarding the per cent yield advantage over control showed that, all the treatments were highly significant over control. The treatment with Imidacloprid 17.8 SL recorded as high as $77.81 \%$ yield increase followed by Spinosad 45SC (65.70\%), Carbofuron $3 \mathrm{G} \quad(56.84 \%)$, nimbicidine $0.03 \% \mathrm{EC}(54.75 \%)$ and manual clipping $(25.84 \%)$. The per cent yield increase in the second year was the highest when compared to first year because of early transplanting, uneven distribution of the pest and lower pest load when compared to first year.

Table.1 Details of different treatments imposed for management of Brinjal shoot and fruit borer (Leucinodes arbonalis (Guenee))

\begin{tabular}{|l|l|l|l|l|}
\hline Treatment & Active ingredient & Product & Chemical group & Dosage \\
\hline T1 & $\begin{array}{l}\text { Nimbicidine 0.03\%EC or } \\
\text { 300ppm }\end{array}$ & $\begin{array}{l}\text { Nimbicidine @ } \\
\text { 0.03\% EC } \\
\text { azadirachtin; } \\
\text { Stanes }\end{array}$ & Biopesticide & $\mathbf{4 ~} \mathbf{~ l ~ L ~}$ \\
\hline T2 & Imidacloprid 17.8 SL & $\begin{array}{l}\text { Sacdor @ } \\
17.8 \% \text { SL; Shivalik } \\
\text { crop sciences }\end{array}$ & Neonicotinoid & $\mathbf{0 . 3 m l ~ / ~ L ~}$ \\
\hline T3 & Spinosad 45SC & $\begin{array}{l}\text { SC; Nagarjun } \\
\text { Agrichem Ltd. }\end{array}$ & Spinosyns & $\mathbf{0 . 3} \mathbf{~ m l ~ / ~ L ~}$ \\
\hline T4 & Carbofuran 3G & Furadan 3G; FMC & Carbamate & \\
\hline T5 & Clipping & - & $\mathbf{5}$ g / plant \\
\hline T6 & Untreated Control & - & $\mathbf{1 0}$ days interval \\
\hline
\end{tabular}


Table.2 Per cent pest reduction and yield advantage of different treatments in Kharif- 2017 (First year)

\begin{tabular}{|c|c|c|c|c|c|c|c|c|c|c|c|c|}
\hline \multirow[t]{3}{*}{ Treatment } & \multicolumn{5}{|c|}{ First treatment (Vegetative stage) } & \multirow{3}{*}{$\begin{array}{l}\text { PTC } \\
(\%)\end{array}$} & \multicolumn{4}{|c|}{ Second treatment (Fruiting stage) } & \multirow[b]{3}{*}{$\begin{array}{l}\text { Yield } \\
\text { (Q/ha) }\end{array}$} & \multirow[b]{3}{*}{$\begin{array}{l}\% \text { yield } \\
\text { increase }\end{array}$} \\
\hline & \multirow{2}{*}{$\begin{array}{l}\text { PTC } \\
(\%)\end{array}$} & \multicolumn{2}{|c|}{7 days } & \multicolumn{2}{|c|}{14 days } & & \multicolumn{2}{|c|}{7 days } & \multicolumn{2}{|c|}{14 days } & & \\
\hline & & $\begin{array}{c}\text { Percent } \\
\text { infestation }\end{array}$ & $\begin{array}{l}\text { Percent } \\
\text { reduction }\end{array}$ & $\begin{array}{c}\text { Percent } \\
\text { infestation }\end{array}$ & $\begin{array}{l}\text { Percent } \\
\text { reduction }\end{array}$ & & $\begin{array}{c}\text { Percent } \\
\text { infestation }\end{array}$ & $\begin{array}{l}\text { Percent } \\
\text { reduction }\end{array}$ & $\begin{array}{c}\text { Percent } \\
\text { infestation }\end{array}$ & $\begin{array}{l}\text { Percent } \\
\text { reduction }\end{array}$ & & \\
\hline T1- Neem Oil & 6.73 & $3.68^{\mathrm{bcd}}$ & 45.3 & $4.15^{\mathrm{c}}$ & 38.3 & $4.45^{\mathrm{c}}$ & $1.81^{\mathrm{b}}$ & 59.5 & $1.99^{\mathrm{bc}}$ & 55.2 & $58.90^{\mathrm{a}}$ & 31.33 \\
\hline T2- Imidacloprid & 7.40 & $3.03^{\mathrm{d}}$ & 59.1 & $3.70^{c}$ & 50.1 & $4.01^{\mathrm{cd}}$ & $1.00^{\mathrm{d}}$ & 75.0 & $1.40^{\mathrm{c}}$ & 65.1 & $64.75^{\mathrm{a}}$ & 44.37 \\
\hline T3- Spinosad & 6.70 & $3.05^{\mathrm{cd}}$ & 54.5 & $3.62^{c}$ & 46.0 & $3.83^{\mathrm{d}}$ & $1.23^{\mathrm{cd}}$ & 67.8 & $1.88^{\mathrm{bc}}$ & 50.9 & $62.00^{\mathrm{a}}$ & 38.24 \\
\hline T4- Carbofuran & 7.35 & $3.70^{\mathrm{bc}}$ & 49.7 & $4.07^{\mathrm{c}}$ & 44.7 & $4.39^{c}$ & $1.48^{\mathrm{bc}}$ & 66.2 & $1.76^{\mathrm{bc}}$ & 60.0 & $61.00^{\mathrm{a}}$ & 36.01 \\
\hline T5- Clipping & 6.98 & $4.04^{b}$ & 42.1 & $4.91^{\mathrm{b}}$ & 29.7 & $5.13^{b}$ & $1.59^{\mathrm{bc}}$ & 69.1 & $2.23^{\mathrm{b}}$ & 56.6 & $57.50^{\mathrm{a}}$ & 28.21 \\
\hline Control & 6.63 & $5.54^{\mathrm{a}}$ & 16.44 & $6.05 a$ & 8.74 & $6.28^{\mathrm{a}}$ & $6.06^{\mathrm{a}}$ & 2.86 & $5.96^{\mathrm{a}}$ & 2.95 & $44.85^{b}$ & 0.00 \\
\hline CD (5\%) & NS & 1.05 & & 0.88 & & 0.63 & 1.303 & & 1.49 & & 8.25 & \\
\hline SED & 1.42 & 0.49 & & 0.34 & & 0.18 & 0.75 & & 0.97 & & 29.95 & \\
\hline CV & 7.82 & 6.25 & & 4.84 & & 3.36 & 10.79 & & 11.19 & & 9.41 & \\
\hline
\end{tabular}

PTC: Pre-treatment count Date of transplanting: 22nd June 2017

Table.3 Per cent pest reduction and yield advantage of different treatments in Kharif- 2018 (Second year)

\begin{tabular}{|c|c|c|c|c|c|c|c|c|c|c|c|c|}
\hline \multirow[b]{3}{*}{ Treatment } & \multicolumn{5}{|c|}{ First treatment (Vegetative stage) } & \multicolumn{5}{|c|}{ Second treatment (Fruiting stage) } & \multirow[b]{3}{*}{$\begin{array}{c}\text { Yield } \\
\text { (Q/ha) }\end{array}$} & \multirow[b]{3}{*}{$\begin{array}{c}\% \text { yield } \\
\text { increase }\end{array}$} \\
\hline & \multirow{2}{*}{$\underset{\%}{\text { PTC }}$} & \multicolumn{2}{|c|}{7 days } & \multicolumn{2}{|c|}{14 days } & \multirow{2}{*}{$\begin{array}{c}\text { PTC } \\
\%\end{array}$} & \multicolumn{2}{|c|}{7 days } & \multicolumn{2}{|c|}{14 days } & & \\
\hline & & $\begin{array}{c}\text { Percent } \\
\text { infestation }\end{array}$ & $\begin{array}{c}\text { Percent } \\
\text { reduction }\end{array}$ & $\begin{array}{c}\text { Percent } \\
\text { infestation }\end{array}$ & $\begin{array}{c}\text { Percent } \\
\text { reduction }\end{array}$ & & $\begin{array}{c}\text { Percent } \\
\text { infestation }\end{array}$ & $\begin{array}{c}\text { Percent } \\
\text { reduction }\end{array}$ & $\begin{array}{c}\text { Percent } \\
\text { infestation }\end{array}$ & $\begin{array}{c}\text { Percent } \\
\text { reduction }\end{array}$ & & \\
\hline $\begin{array}{c}\text { T2- } \\
\text { Imidacloprid }\end{array}$ & $4.82^{b}$ & $1.92^{c}$ & $60.16^{c}$ & $2.21^{\mathrm{c}}$ & 54.14 & $4.11 \mathrm{a}$ & $1.36^{\mathrm{cd}}$ & 66.90 & $1.26^{\mathrm{d}}$ & 69.34 & $76.70^{\mathrm{a}}$ & 77.81 \\
\hline T3-Spinosad & $5.61^{\mathrm{a}}$ & $2.64^{b}$ & $52.94^{\mathrm{c}}$ & $2.75^{\mathrm{c}}$ & 50.98 & $4.08 \mathrm{a}$ & $1.77^{\mathrm{bc}}$ & 56.61 & $1.50^{\mathrm{cd}}$ & 63.23 & $71.50^{\mathrm{ab}}$ & 65.70 \\
\hline T5- Clipping & $5.56^{\mathrm{a}}$ & $3.11^{\mathrm{b}}$ & $44.86^{\mathrm{b}}$ & $4.17^{b}$ & 25.00 & $4.56 a$ & $2.19^{b}$ & 51.97 & $2.70^{b}$ & 40.78 & $54.00^{c}$ & 25.84 \\
\hline Control & $5.78^{\mathrm{a}}$ & $5.92^{\mathrm{a}}$ & $-2.42^{\mathrm{a}}$ & $5.98^{\mathrm{a}}$ & -3.46 & $4.40 \mathrm{a}$ & $4.58^{\mathrm{a}}$ & -4.09 & $4.61^{\mathrm{a}}$ & -4.77 & $43.20^{\mathrm{d}}$ & $\mathbf{0 . 0 0}$ \\
\hline CD $(5 \%)$ & 0.71 & 1.02 & & 1.28 & & 1.16 & 1.37 & & 1.64 & & 3.79 & \\
\hline SED & 0.22 & 0.46 & & 0.72 & & 0.59 & 0.83 & & 1.19 & & 6.32 & \\
\hline $\mathrm{CV}$ & 3.51 & 6.73 & & 7.91 & & 6.88 & 10.97 & & 13.17 & & 4.75 & \\
\hline
\end{tabular}

PTC: Pre-treatment count

Date of transplanting: $23^{\text {rd }}$ May 2018 
Brinjal shoot and fruit borer is economically important and most obnoxious key pest of Brinjal in the entire South and South East Asian countries (Dhankar 1988; Islam and Karim 1993; Rahman 1997; Alam et al., 2003) causing severe yield losses. Whereas, in the Indian Himalayas especially, vegetable growing belts of Uttarakashi district of Uttarakhand are severely affected by this pest and the pest population density is always above ETL. Moreover, farmers of this region mostly rely up on calendar spray of conventional insecticides belonging to carbamate and organophosphate groups and mechanical methods like, clipping off of infected shoots and fruits for control of the pest. The increased dependence on pesticides, calendar based sprays, short residual action of certain group of insecticides have not only increased the cost of production but also have resulted in several problems like resurgence of pest, health hazards and pesticide residues in edible fruits (Kabir et al., 1996).

Considering the severe pest infestation and losses incurred by farmer, the six treatments were designed keeping in mind the farmers practices and insecticides easily available for the farmers once recommendations are developed. The studies conducted by Latif et al., (2010) showed that azadirachtin (a neem product) could reduce the per cent pest damage by up to $31 \%$ but, could barely increase the yield of crop. Moreover, azadirachtin treated plots recorded the highest per cent pest infestation of $3.04 \%$ after first spray, which was in accordance with our study, wherein, we recorded $3.68 \%$ and $2.79 \%$ pest infestation 7 days after first spray in first and second year respectively. The investigations of Rahman et al., (2009), Talekar (2002), Arida et al., (2003), Satpathy et al., (2005) concluded that, Removal and prompt destruction of the BSFB infested shoots and fruits at regular intervals have been suggested as an effective strategy to manage the EFSB on eggplant in South and Southeast Asia. Moreover, Duca et al., (2004), Singh et al., (2005), Rath and Maity (2005) and Srinivasan (2008) reported that, mechanical clipping of infested shoots and leaves lowers the incidence of pest on damaged fruits, attributes to prevention in dispersal or dissemination of the pest and significantly increases the yield.

With respect to the chemical management strategies, the experiments of Shirale et al., (2012) showed that, spinosad $45 \mathrm{SC}$ is an effective insecticide for management of Brinjal shoot and fruit borer. Two foliar sprays of Spinosad $45 \mathrm{SC}$ at vegetative and reproductive stage increased the per cent fruit yield by $64.30 \%$ over control and these results were in close corroboration with our results, wherein, $65.70 \%$ yield increase was recorded in second year. However, only $38.24 \%$ yield increase was recorded in first year which was even significantly superior over control. Moreover, Latif et al., (2010) reported the effectivity of carbamte group insecticide (Carbosulfon, Marshal 20EC) against the insect pest, wherein, they recorded up to $71.56 \%$ reduction in per cent pest damage. These results were in close accordance with our study, where, we could record as high as $66.2 \%$ pest reduction in pest damage in the first year (Kharif-2017) after second application of carbofuron granules (carbamate group insecticide) in reproductive stage.

Although, Imdiacloprid 17.8SL is recommended for the management of sucking pests in brinjal, the foliar spray of the same insecticide at recommended field doses could effectively manage the pest population of BSFB. Two sprays of Imidacloprid 17.8SL at $0.3 \mathrm{ml}$ per Litre field dose were highly efficient in per cent pest reduction of $50 \%$ or more in both the seasons. However, in Kharif2017 a lowest of $50.1 \%$ and highest of $75 \%$ reduction in pest population was recorded 
after first and second spray respectively. The per cent yield increase was significantly superior over the control and highest among all the treatments, as high as $77.81 \%$ yield was increased in second year and $44.37 \%$ in first year after two sprays of Imdiacloprid 17.8SL. The present investigation concludes that, Imidacloprid $17.8 \mathrm{SL}$ is the best insecticide that can be recommended to the farmers of vegetable growing belts of Uttarakashi district of Uttarakhand, and for pesticide rotation, Spinosad 45SC and Carbofuron $3 \mathrm{G}$ soil application can be suggested. While, regular manual clipping of infected shoots and fruits can be included in the IPM practice to prevent pest dispersal or dissemination and supplement other control measures for efficient management of Brinjal fruit and shoot borer in the region.

\section{Acknowledgement}

The authors are grateful to Indian Council of Agricultural Research (ICAR) for the financial assistance during conduction of the research activity.

\section{Conflict of interest}

All the authors have thoroughly reviewed the article and therefore have no conflict of interest for publication of the article.

\section{References}

Alam, S. N., Rashid, M. A., Rouf, F. M. A., Jhala, R. C., Patel, J. R., Satpathy, S., Shivalingaswamy, T. M., Rai, S., Wahundeniya, I., Cork, A., Ammaranan, C., and Talekar, N. S. (2003). Development of an integrated pest management strategy for eggplant fruit and shoot borer in South Asia. Technical Bulletin 28, AVRDC-The World Vegetable Center, Shanhua, Taiwan. 66 pp.
Annual Report: Asian Vegetable Research and Development Center (AVRDC), P.O. 42, Shanhua, Taiwan, 741 ROC (1995).

Arida, G. S., Duca, A. A., Punzal, B. S., and Rajotte, E. G. (2003). Management of the brinjal fruit and shoot borer, Leucinodes orbonalis (Guenee): Evaluation of farmer's indigenous practices. In: Overview of the Southeast Asia Site in the Philippines. pp. 45-47.

Atwal, A. S., and Dhaliwal, G. S. (2007). Agricultural pests of South Asia and their management, 5th edn. Kalyani Publishers, India

Chakraborti, S., and Sarkar, P. Kanti. (2011). Management of Leucinodes orbonalis Gunee on eggplants during the rainy season in India. Journal of Plant Protection Research, 51(4), 325-328.

Dhankar, D. S. (1988). Progress in resistance studies in eggplant (Solanum melongena L.) against shoot and fruit borer of brinjal (Leucinodes orbonalis Guen.) infestation. Tropical Pest Management, 34, 343-345.

Duca, A. A., Arida, G. S., Punzal, B. S., and Rajatte, E. G. (2004). Management of eggplant fruit and shoot borer, Leucinodes orbonalis (Guenee): Evaluation of farmers' indigenous practices. Philippine Entomologist, 18(2), 172-173.

Eshwara Reddy., and Srinivasa, S. G. (2004). Management of shoot and fruit borer, Leucindoes orbonalis (Guen.) in brinjal using botanicals/oils. Pestology, $28,50-52$.

FAO. (2007). FAOSTAT data 2005. http://www.fao.org

Harish, D. K., Agasimani, A. K., Imamsaheb, S. J., and Patil, S. S. (2011). Growth and yield parameters in brinjal as influenced by organic nutrient management and plant protection 
conditions. Research Journal of Agricultural Sciences, 2(2), 221-225.

Islam, M. N., and Karim, M. A. (1991). Management of the brinjal shoot and fruit borer, Leucinodes orbonalis Guen, (Lepidoptera: Pyralidae) in field. In: Annual Research Report 1990-91. Entomology Division, Bangladesh Agriculture Research Institute, Joydebpur, Gazipur, $44-46$.

Jagginavar, S. B., Sunitha, N. D., and Biradar. A. P. (2009). Bioefficacy of flubendiamide 480 SC against brinjal fruit and shoot borer, Leucinodes orbonalis Guen. Karnataka Journal of Agricultural Sciences. 22(3), 712- 713.

Kabir Roul, F. M. A., Islam, M. N., and Malaker, P. K. (1996). Efficacy of different insecticides in controlling brinjal shoot and fruit borer, Leucinodes orbonalis Guen. University Journal of Zoology, Rajasthan University, Udaipur, 13, 1-8.

Latif, M. A., Rahman, M. M., and Alam, M. Z., (2010). Efficacy of nine insecticides against shoot and fruit borer, Leucinodes orbonalis Guenee (Lepidoptera: Pyralidae) in eggplant. Journal of Pesticide Science, 83, 391397.

Lovelock, Y. (1972). The Vegetable Book. George Allen and Unwin Ltd., London.

Patial, A., and Mehta, P. K. (2008). Pest complex of brinjal and their succession under mid hills of Himachal Pradesh. Journal of Insect Science, 21, 67-71.

Rahman, M. M. (2006). Vegetable IPM in Bangladesh. In: Radcliffe EB, Hutchison WD (eds) Radcliffe's IPM world textbook. http://www. ipmworld.umn.edu/chapters/ rahman.htm, University of Minnesota, St. Paul, MN, USA

Rahman, M. M., Ali, M. R., and Hossain, M. S. (2009). Evaluation of combined management options for managing brinjal shoot and fruit borer. Academic Journal of Entomology, 2(2), 92- 98.

Rahman, A. K. M. Z. 1997. Screening of 28 brinjal line for resistance/tolerance against the brinjal shoot and fruit borer. Annual Report. Entomology Division, Bangladesh Agricultural Research Institute, Joydebpur, Gazipur, Bangladesh. pp. 32-35.

Rath, L. K., and Maity, B. K. (2005). Evaluation of a nonchemical IPM module for management of brinjal shoot and fruit borer. Journal of Applied Zoology Research, 16, 3-4.

Reghupathy, A., Palanisamy, S., Chandramohan, N., and Gunathilagaraj, K. (1997). A guide on crop pests. Sooriya Desktop Publishers, Coimbatore. 264.

Satpathy, J. M. (2005). Field test with granulated insecticides for the control of Leucinodes orbonalis Guenee on brinjal. Indian Journal of Horticulture Science, 43(12), 1081-1086.

Shirale, D., Patil, M., Zehr, U., and Parimi, S. (2012). Evaluation of newer insecticides for the management of brinjal fruit and shoot borer Leucinodes orbonalis (Guenee). Indian Journal of Plant Protection, 40(4), 273-275.

Singh, H. S., Sidhar, V., and Naik, G. (2005). Evaluation of some alternative measures against brinjal shoot and fruit borer, Leucinodes orbonalis Guenee. under Bhubaneswar climatic conditions. Journal of Applied Zoology Research, 16, 123-125.

Singhal, V. (2003). Indian Agriculture. Indian Economic Data Research Centre, New Delhi.

Srinivasan, R. (2008). Integrated Pest Management for eggplant fruit and shoot borer (Leucinodes orbonalis Guenee) in south and Southeast Asia: past, present and future. Journal of 
Biopesticides. 1, 105-112.

Talekar, N. S. (2002). Controlling brinjal fruit and shoot borer: A simple, safe and economical approach. International Cooperators' Guide, AVRDC Pub. \#02-534. Asian Vegetable Research and Development Center, Shanhua, Taiwan. 4 p.

Taylo, L., Sison, M. L. J., and D. M. Hautea. (2016). Use of artificial infestation for field bioefficacy assessment of $\mathrm{Bt}$ eggplant against the eggplant fruit and shoot borer, Leucinodes orbonalis Guenee (Lepidoptera: Crambidae). Philippines Agricultural Science, 99:119-126

Welfare, F. (2019). Horticultural statistics at a glance 2018. OUP Catalogue.

\section{How to cite this article:}

Jaiprakash Gupta, ARNS. Subbanna, Johnson Stanley, Amit Umesh Paschapur and Krishna Kant Mishra. 2020. Devising an Effective Management Strategy against Brinjal Shoot and Fruit Borer [Leucinodes orbonalis (Guenee)] under Hill Agriculture in Uttarakhand, Himalayas. Int.J.Curr.Microbiol.App.Sci. 9(11): 58-66.

doi: https://doi.org/10.20546/ijcmas.2020.911.006 